\title{
STUDIUL IHTIOPARAZITOFAUNEI BAZINULUI ACVATIC AI REZERVAȚIEI ȘTIINȚIFICE „CODRII”
}

\author{
Rusu Ștefan, Gologan Ion, Rusu Vadim ${ }^{1}$ \\ Institutul de Zoologie al MECC, or. Chișinău, Republica Moldova, \\ ${ }^{1}$ Universitatea de Stat din Moldova, or. Chișinău, Republica Moldova \\ E-mail:gologanionel@gmail.com
}

https://doi.org/10.53937/9789975315975.59

Principalele sarcini a pisciculturii sunt creșterea producției piscicole și îmbunătățirea calității produselor de pește. Implementarea planificată a acestora se bazează pe numeroși factori importanți ca: monitorizarea hidrologică; biocenologică și parazitologică a bazinelor piscicole. Studiul parazitologic al gospodăriilor piscicole permite atât identificarea acestora, cât și implimentarea rapidă a măsurilor de profilaxie și de tratament (Новак, Новак, 2012).

Unul dintre factorii ce reduc rentabilitatea pisciculturii, sunt bolile parazitare. Starea de sănătate a peștilor este influențată de mai mulți factori, iar la bază fiind următorii: habitatul cu condițiile de întreținere, disponibiliatea bazei furajere și influența diferitor organisme patogene sau condiționat patogene (Селиверстов, Мамонтов, 2000).

Dezvoltarea cu succes a pisciculturii în mare măsură este determinată de bunăstarea gospodăriilor piscicole. Bolile parazitarea și infecțioase ale peștilor, provoacă pierderi economice semnificative și sunt factorii de bază ce încetinesc dezvoltarea pisciculturii (Аксашева, Васильев, 2013)

Scopul prezentei lucrări constă în studiul ihtioparazitofaunei bazinului acvatic al Rezervației Științifice "Codrii" și elaborarea unor măsuri de diminuare și combatere a helmintozelor depistate.

Cercetările, privind studiul ihtioparazitofaunei peștilor bazinului acvatic au fost efectuate pe parcursul anului 2018. Examenul parazitologic al peștilor capturați cu scopul identificării speciilor de ecto- și endoparaziți, s-a efectuat după metodele uzuale, acceptate în ihtioparazitologie 
(Быховская-Павловская, 1985). După realizarea examenului parazitologic a urmat etapele de recoltare și fixare a paraziților în soluție de etanol 70\% și Barbagallo. Examinarea paraziților s-a realizat cu ajutorul, lupei, microscopului binocular și a microscopului cu videoadapter NOVEX HOLLAND. Diagnosticul diferențiat al paraziților depistați a fost realizat conform determinatorului (Баyep, 1987).

Examenului parazitologic, au fost supuși în total 23 exemplare de pești, capturați prin intermediul uneltelor de pescuit (undițe, ietre, plase etc.), din bazinul acvatic al Rezervației Științifice "Codrii" dinte care: Caras (Carassius gibelio (Bloch, 1782)) - 7 exemplare; Cosaș (Ctenopharyngodon idella (Vallenciennes, 1844) - 1 exemplar; Crap (Cyprinus carpio Linnaeus, 1758) - 9 exemplare; Sânger (Hypophthalmichthys molitrix (VaIlenciennes, 1844) - 5 exemplare și Șalău comun (Sander lucioperca (Linnaeus, 1758) - 1 exemplar.

Rezultatul studiului parazitologic efectuat la peștii capturați, a pus în evidență specii de ecto- și endoparaziți conform tabelului și foto de mai jos:

Tabel. Parazitofauna speciilor de pești din bazinul acvatic al Rezervației Științifice "Codrii"

\begin{tabular}{|c|c|c|c|c|c|c|}
\hline \multirow{3}{*}{$\begin{array}{l}\text { Nr. } \\
\text { d/o }\end{array}$} & \multirow{3}{*}{$\begin{array}{l}\text { Speciile } \\
\text { de pești } \\
\text { exami- } \\
\text { nate }\end{array}$} & \multirow{3}{*}{$\begin{array}{l}\text { Numărul } \\
\text { de exem- } \\
\text { plare exa- } \\
\text { minate }\end{array}$} & \multicolumn{4}{|c|}{ Specii de paraziți } \\
\hline & & & \multicolumn{2}{|c|}{ Endoparaziți } & \multicolumn{2}{|l|}{ Ectoparaziți } \\
\hline & & & $\begin{array}{l}\text { Denumirea } \\
\text { speciei }\end{array}$ & $\begin{array}{l}\text { II } \\
\text { (exemplare) }\end{array}$ & $\begin{array}{l}\text { Denumirea } \\
\text { speciei }\end{array}$ & $\begin{array}{l}\text { II } \\
\text { (exemplare) }\end{array}$ \\
\hline \multirow{2}{*}{1} & \multirow{2}{*}{ Caras } & \multirow{2}{*}{7} & \multirow{2}{*}{ - } & \multirow{2}{*}{ - } & Argulus sp. & 8 \\
\hline & & & & & Lernaea sp. & $1-17$ \\
\hline \multirow{2}{*}{2} & \multirow{2}{*}{ Crap } & \multirow{2}{*}{9} & \multirow{2}{*}{$\begin{array}{l}\text { Philometroi- } \\
\text { des sp. }\end{array}$} & \multirow{2}{*}{1} & Argulus sp. & 10 \\
\hline & & & & & Lernaea sp. & $8-12$ \\
\hline 3 & Sânger & 5 & $\begin{array}{l}\text { Diplostomum } \\
\text { sp. }\end{array}$ & $5-130$ & Sinergasilus sp. & $12-28$ \\
\hline 4 & Șalău & 1 & - & - & Argulus sp. & 6 \\
\hline 5 & Cosaș & 1 & - & - & - & - \\
\hline
\end{tabular}




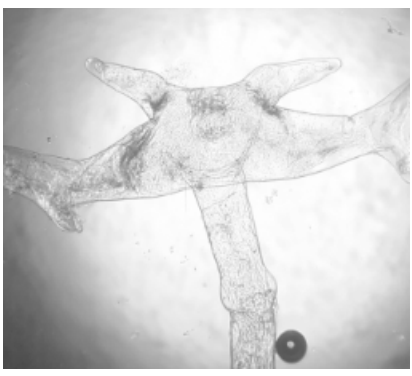

a

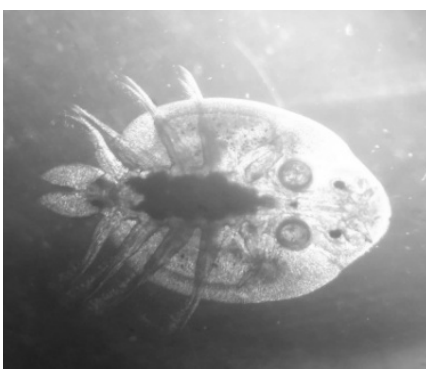

$b$

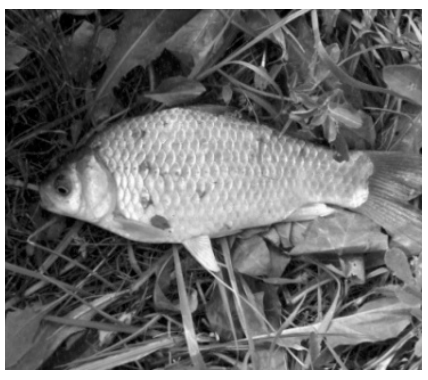

C

Foto: a )Lernaea sp. b) Argulus sp. c) Crap cu leziuni cutanate cauzate de crustaceele ectoparazite.

În scop de combatere a paraziților la peștii din acest bazin acvatic examinat se recomandă:

1. Administrarea cu hrana a preparatului antihelmintic Râbolic conform instrucțiunii de utilizare.

2. Mărirea procesului de mineralizare a apei și efectuarea dezinfecției bazinului acvatic prin utilizarea varului nestins sau a celui stins în proporție de $150 \mathrm{~kg} / \mathrm{ha}$ cu o repetare a prelucrării peste 2 săptămâni.

Investigațiile au fost realizate în cadrul proiectului 15.817.02.12 F, finanțat de Consiliul Suprem pentru Știință și Dezvoltare Tehnologică al Academiei de Științe a Moldovei. 